University of Nebraska - Lincoln

DigitalCommons@University of Nebraska - Lincoln

Faculty Publications in Educational

Administration

Educational Administration, Department of

2020

Reframing community (dis)engagement: the discursive connection between undemocratic policy enactment, minoritized communities and resistance

James S. Wright

Taeyeon Kim

Follow this and additional works at: https://digitalcommons.unl.edu/cehsedadfacpub

Part of the Educational Administration and Supervision Commons

This Article is brought to you for free and open access by the Educational Administration, Department of at DigitalCommons@University of Nebraska - Lincoln. It has been accepted for inclusion in Faculty Publications in Educational Administration by an authorized administrator of DigitalCommons@University of Nebraska - Lincoln. 


\title{
Reframing community (dis)engagement: the discursive connection between undemocratic policy enactment, minoritized communities and resistance
}

\author{
James S. Wright ${ }^{1}$ and Taeyeon Kim ${ }^{2}$ \\ 1 Department of Educational Leadership, San Diego State University, \\ San Diego, CA, USA; \\ 2 Department of Educational Administration, Michigan State University, \\ East Lansing, MI, USA. Present affiliation: Department of Educational \\ Administration, University of Nebraska-Lincoln, Lincoln, NE, USA \\ Corresponding author - James S. Wright jwright6@sdsu.edu Department of Educational \\ Leadership, San Diego State University, San Diego, CA, USA \\ ORCID \\ James S. Wright http://orcid.org/0000-0002-5285-4767 \\ Taeyeon Kim http://orcid.org/0000-0002-2020-9851
}

\begin{abstract}
While studies have examined leadership efforts to improve community engagement, less is known about how deeply rooted structured discourses, systems, and practices influence leadership actions and responses from communities. Deficit approaches to educational policy reform are pervasive in the most historically marginalized
\end{abstract}

Published in Journal of Education Policy, 2020

doi:10.1080/02680939.2020.1777467

Copyright (C) 2020 Informa UK Limited, trading as Taylor \& Francis Group

Submitted 10 July 2019; accepted 29 May 2020; published 14 Jun 2020

Citation: James S. Wright \& Taeyeon Kim (2020): Reframing community (dis)engagement: the discursive connection between undemocratic policy enactment, minoritized communities and resistance, Journal of Education Policy, DOI: $10.1080 / 02680939.2020 .1777467$ 
communities and school districts in the United States (US). Drawing on critical policy analysis, this study examines a disengaged school district's leadership of a Federal School Turnaround Policy from the perspectives of minoritized communities in an urban US school district. We analyzed deficit policy discourses, its enactment, and leadership practices using interview data and archived documents. This study found pathological discourses and deficit frames of minoritized communities, embedded in policy enactment, which directly led to leadership practices resulting in community resistance. In this way, we (re)frame disengaged school leadership; the resistance and the tension in response to pathological and deficit structures and ideologies as, at minimum, healthy attempts of redistributing justice and democracy. In addition, our findings highlight that discourses and enactment of turnaround school reforms were intertwined with undemocratic and racialized practices.

Keywords: Critical policy analysis, community engagement, community disengagement, epistemology, urban education, turnaround reform

\section{Introduction}

This paper draws on critical policy analysis and contextualizes educational policy as a discursive practice informed by western cultures and ideologies. Under the guise of objectivity, and positioned as universal, we argue that educational policy informed by Western culture and ideologies are harmful to divergent cultures and ways of knowing common to the multitude of minoritized communities, particularly Black and Brown communities (e.g., Battiste 2013; Gillborn 2005; Mackey 2017; Stein 2004). Thus, we focus on policy discourses and practices which deficitize, marginalize, and ignore Black and Brown cultures, communities, and their perspectives. The findings in this study reveal commonly constructed discourses that promotes power and interests of dominant groups, identifiable across multiple global contexts. Therefore, this study is relevant to an international audience of researchers and educators who are dealing with related issues of inequity. Such transnational phenomena include turnaround school reforms, undemocratic practices and policies, and deficit perspectives of minoritized populations. This study conducted in the United States (US) found widespread deficit approaches embedded in educational policy reform aimed at minoritized, Black and Brown communities and school districts. These deficit-based policy approaches reveal a long history that covers the most historically marginalized groups in the US, including Blackamericans, Latinx, Native and Indigenous 
Americans. Furthermore, these deficit policy approaches were found impacting minoritized communities and their school districts throughout every region in the US (Mackey 2017; Radd, Grosland, and Steepleton 2019; Trujillo et al., 2014; Wright et al., 2018)

We analyzed educational policy enactment and the impact of power imbalances in a majority-minority urban school district in a US city renamed 'Urbanville.' Latinx and Blackamericans from among the district's most impoverished communities and families make up over 85 percent of the students, while over 90 percent of school administrators, teachers, and staff in the district are whites, many of whom reside in nearby affluent suburbs. Broader community responses to racialized leadership discourses and practices in the district are also analyzed. Beginning in 2013, a Federal takeover policy (called 'Turnaround'), designed to raise test scores, was enacted in the Urbanville district under the leadership of the city's mayor. As a result, discriminatory discourses and policy enactment caused a collective of parents and community members to resist and galvanize. The galvanization of parents and community members in the district centered around the removal of Marcus King, the only Blackamerican principal in the district at the time. Contrasting perceptions of King's effectiveness as an educator commenced between a small group of powerful, white educational leaders controlling the district who minimized King's leadership; and the Black and Latinx parents and community members who loved and valued King's leadership, and whose children made up the majority of the district and over 90 percent of students in King's school.

This paper centers disengaged school district leadership from the concerns and perspectives of the broader Black and Latinx community members, including parents, educators and community activists. We specifically analyze 1) how deficit policy discourses and narratives framed minoritized communities and 2) how these policy discourses informed leadership practices, resulting in community disengagement, resistance and mobilization in the Urbanville district (Luet, 2017). We conclude our paper by highlighting how deeply bureaucratic structures and school systems are racialized, can and do reproduce inequity, and are propped up by powerful, undemocratic, and racist ideology. In this way, we reframe the resistance and the tension in response to these structures and ideologies as, at minimum, healthy attempts of 
redistributing justice and democracy. Our findings also highlight that discourses and enactment of Turnaround school reforms (e.g. school and district takeovers) are intertwined with undemocratic practices and deficit views of minoritized communities which have been deeply rooted within the culture and history of US education policy (see Morel 2018; Stein 2004; Wright et al., 2018).

\section{Review of literature}

First, we review literature on policy as discursive practice focusing on the culture of policy in the US. We underline critical policy analysis as a way of understanding deeper meanings in educational policy such as racialized policy enactment, community organization, mobilization, and resistance. Second, we review studies on community engagement from the view of democracy.

\section{Policy as discursive practice: culture of policy in the US context}

While conventional policy analysis is grounded in the notion that policy is a tool for fixing problems of practice and producing a desired outcome (Radd, Grosland, and Steepleton 2019), the view of policy as discourse has challenged conventional analysis by focusing instead on underlying ideas, assumptions, and narratives informing policy (Kim 2020; Bacchi 2000; Ball 1993). Thus, a critical policy analysis encourages assessment beyond the policy text to the underlying narratives embedded within policy along with the symbols and language that define the policy process; from legislation to local enactment ( Abraham et al. 2019; Gillborn 2010; Radd, Grosland, and Steepleton 2019; Smyth and Robinson 2015; Stein 2004; Wright et al., 2018).

Critical policy analysis focuses on power dynamics, positing the view that policy can be understood as a process of reproducing discourses and practices which promote the interests of dominant groups; contrasting common universal, science/evidence-based, and objective truth rhetoric (Levinson, Sutton, and Winstead 2009; Molla and Gale 2018). Thus, these critical approaches enable researchers to reveal power dynamics and control mechanisms in education which are incorporated in state-level or national-level policies as well as policies 
in the global context (e.g., Diem et al. 2014). In this way, critical policy methodologies have been powerful tools for researching how minoritized people and communities experience policy across various international contexts.

While critical policy analysis throughout international contexts highlights important differences from US contexts, critical commonalities also emerge in the ways that ideologies and economic interests drive policy. Studies reveal that deeply embedded, deficit laden, ideologies emerge with implementation over time (Mackey 2017; Battiste 2013; Gillborn 2005; Stein 2004; Wright et al., 2018). For example, Mackey (2017), an Indigenous US scholar, identifies a historic tension found between three decades of US educational policies aimed at improving educational outcomes for all students through increased standardization and accountability measures; and Federal Indian policies and laws which have been systematically and effectively working to eradicate Native ontologies, epistemologies, and languages. Battiste (2013), an Indigenous Canadian scholar with decades of administration and teaching experience in First Nation Canadian schools, aims her 'discursive arrow' and research at Federal and provincial policy and systems and the inequities that they produce. Gillborn (2005) frames education policy in the UK as an act of white supremacy identifiable by looking beyond superficial rhetoric informing policy and practice, and at the material and ideology at work legitimizing and exacerbating racialization and inequity.

Additionally, Stein (2004) identifies over 6o years of equity-oriented educational policies reproducing tragically similar failed outcomes in the US, driven by what she discursively identifies as the culture of education policy. Within this frame, culture can be understood as assumptions, norms, values, and ways of knowing that are shared within a particular group of people (Kim 2020; Khalifa 2018a, 2018b). Stein (2004) identifies the culture of education policy as a framework which interrogates how the educational policy process frames the ways we see individuals and groups. The concept of the culture of policy is helpful for critically examining the assumptions built into policy by challenging 'the ways in which policies shape institutional and individual perceptions and treatments of those they aim to serve' (Stein 2004, p. 12). 
State led educational policy: racialized enactment

In the U.S., extant studies have reported deficit framing of minoritized communities in discourses and enactment of education policy. For example, Radd, Grosland, and Steepleton's (2019) critical analysis of Minnesota's Desegregation Rule found that, although the Rule was framed to reduce structural and social inequality, the de-emphasis on racial equity, and the over-emphasis on bureaucracy and procedure helped to perpetuate deep structural, institutionalized, systemic, and social forms of inequity and racism.

Studies on school takeover policy revealed that enactment overran the legislated criteria of subpar fiscal and educational outcomes; instead, the racial makeup of the school districts were found to be key determinants of enactment (e.g., Arsen et al. 2016; ; Morel 2018; Radd, Grosland, and Steepleton 2019; Wright et al., 2018). Morel's (2018) examination of school district closings resulting from takeovers across several states, found race, economics, and politics as equally important contributors to state takeovers. Several policy analyses of stateled takeovers of districts in Michigan verify Morel's (2018) claims (Arsen et al. 2016; Bowman 2013; Wright et al., 2018). For example, analysis of Michigan takeovers revealed that districts with a majority of Black student populations were taken over, even in instances when majority white districts showed identical and worst fiscal condition (Arsen et al. 2016; Wright et al., 2018). These empirical findings reveal incoherent and inconsistent policy enactments which urban education researchers and reformers find alarming.

Reaction to policy: community organization and political action as resistance

In response to a growing awareness around deficit-discourses undergirded by Federal and State policy, research shows growing evidence that community organizing groups are building political networks and navigating the political environment necessary for relevant and responsive school reform (Abraham et al. 2019; Jasis 2013; Fuentes 2012; Morel 2018; Warren 2011). For example, Fuentes' (2012) ethnography described parent and community group efforts to address the achievement gap for Blackamerican students in their school district as 'a site of radical resistance' (p. 628). In Texas, the Industrial 
Areas Foundation (IAF) became an influential political force for educational policy and school reform, and effective educational reform strategies that reflect local community aims were found in urban districts in New York City (Warren 2005, 2011). In addition, the Opt-Out Movement in New Jersey in 2015, was identified as a middle-class white community's effective resistance to high stakes standardized instruction and testing (Abraham et al. 2019). These movements show that organized, community based education reform involves diverse actors and their dynamic actions in developing, enacting, and revising education policies.

Nonetheless, this community organizing and political engagement toward school reform is not a new phenomenon in Blackamerican history. Historians document these efforts occurring post-Enslavement and again in the post-Civil Rights Era in the U.S. (Anderson 1988; Morel 2018). In his historical analysis of The Education of Blacks in the South, 1860-1935, Anderson (1988) found that pre-Civil Rights Era Blacks, in a cash-short economy, and disenfranchised by public school authorities, paid from their limited resources to educate their children. Furthermore, in 1964, on the heels of Civil Rights legislation in the U.S., community and economic opportunity and action programs were legislated to help maximize community participation in efforts to alleviate poverty (Morel 2018). As a result, Greenstone and Peterson (1976) noted that Blackamerican participation in community-based programs in many urban cities ignited local political struggles which dramatically changed American politics. These community mobilizations and political networks led to the first wave of Black elected officials such as mayors, city council, and school board members, across large urban US cities in the 1970 and 1980s. This paradigm shift impacted policy, curriculum and ignited new and relevant reforms (Morel 2018). These studies, particularly in the historical context of minoritized groups in the U.S., reveal that community organizations and their grassroot actions, borne out of resistance, have and can fundamentally impact school operations, and have and can ignite educational reforms.

\section{The value and power of community engagement in education}

The involvement, and engagement of parents, families, and communities is of universal value in education (Crozier 2014). Citing researched perspectives from across nine countries and four continents, Crozier 
(2014) argues that parental, family, and community involvement is a formidable force toward transforming the school context for a range of underserved student populations. Echoing Crozier (2014), literature in the US highlights the importance of parental and community engaged leadership and its relationship to successful school reform and student success (Abraham et al. 2019; Henderson and Mapp 2002; Ishimaru 2014; Khalifa 2018b).

While some scholars distinguish parental engagement from community engagement (e.g., Epstein, Comer), we find parental and community engagement to be interconnected (Auerbach 2010; Warren 2005, 2014; Schutz 2006). We view community engagement as incorporating parental engagement in schooling. According to Schutz (2005), community refers to a common condition that people share through place, culture, emotions, and occupation. Thus, we define community engagement as democratic participation from community members, which can be identifiable by common, race, ethnicity, language, neighborhoods and/or cultures; initiated by all matters relative to the impact of schools; with an understanding of the relationship schooling can and does have on the trajectory of their communities.

Isolating urban community culture and knowledge from schooling

Scholars suggest that impactful educational reform should be responsive towards and respectful of communities and cultures that students bring into their schools, and should not be patronizing, imposing nor condescending (Anderson 1998; Ishimaru 2014; Khalifa 2018a; Warren 2005). In this respect, educational researchers argue that culturally responsive or proficient leadership needs to be central to developing effective leaders (Gates et al. 2019; Khalifa 2018a, 2018b; Lindsey, Roberts, and CampbellJones 2013). Lindsey, Roberts, and CampbellJones (2013) argue that developing leaders who understand diverse cultures and groups are critical to challenging the status quo and achieving social justice-oriented goals.

Critical policy analysts argue that deficit models are embedded in educational policies. For example, Anderson (1998) asks who gets to participate, in what areas, and under what conditions. Research has shown that minoritized schools, students and communities are viewed as problems, and not as resources capable of propelling their 
neighborhoods; thus, minoritized students feel ignored by their schools and curriculum (Ishimaru 2014; Ishimaru et al. 2016; Smyth 2006; Warren 2005; Wright and Tabrizi, 2020). In the urban education context of the U.S., where many diverse and minoritized communities (e.g., racial, ethnic, linguistic, various levels of SES) live, most urban schoolteachers and staff commute to their schools, and have little connection with their students and their neighborhoods (Warren 2005). This disconnection is stifling, as scholars argue that authentic change should be connected to revitalizing urban communities and connected to investing or reinvesting in the culture and the people in urban/minoritized communities (Anderson 1998; Warren 2005). Such racialized and economically motivated factors have led to a significant amount of resistance to educational policy and practices in urban contexts (Wright and Tabrizi, 2020).

\section{Community engagement, democracy, and resistance}

Preventing or rejecting community engagement in education for ideological, or any other reason, is undemocratic. Research shows that community engagement in education is a hallmark of a functioning democracy (Anderson 1998; Crouch 2016; Della Porta 2015) and leads to student achievement and academic progress (Crowson and Boyd 2001; Henderson and Mapp 2002; Ishimaru 2014; Molla and Gale 2018; Khalifa 2018a). The Civil Rights Movements in the U.S. demonstrated that organized community resistance can contribute to making schools and educational policies more democratic and just for all. Consequently, US history is inundated with bipartisan, liberal and conservative resistance to Civil Rights agendas and legislation during the 1960s (Anderson 2016; Singh 2018). Similarly, researchers cite a long history of schools resisting the participation of minoritized, urban, and impoverished families and community members (Luet, 2017; Morel 2018; Schutz 2006). Nonetheless, U.S. Secretary of Education, Arne Duncan, proclaimed education the foremost contemporary civil rights issue during the 5oth anniversary of the Civil Rights Act of 1964 (Duncan 2014). Thus, often lost in contemporary Civil Rights proclamations and discourses are the deep levels of systemic and structural resentment toward Blacks and other minoritized groups in the U.S. and their demands for social, economic, and political justice, and equity. 
In summation, community resistance to existing problems in school systems should be understood as a way to redress unjust educational policy and practice. It is important to consider community disengagement and/or resistance as tools to engage or reengage with schools. Building on the above literature, our analysis focuses on ideologies and discourses uncovered beyond the policy text in the context of community resistance to policy enactment.

\section{Context of the study}

The study site, Urbanville, has a total of 30 schools from elementary to high schools. The Urbanville school district consisted of over 19,000 students, and approximately 1,400 teachers (Department of Education 2018). The district boasts student to teacher ratios that were significantly better than the state and national averages (Department of Education 2018). The Urbanville district has over 85 percent minoritized students (mostly Blackamerican and Puerto Rican); in contrast, just under 90 percent of teachers and administrators in the district were white (Urbanville Minority Teachers 2015). ${ }^{1}$

In Urbanville, 6o percent of the entire city's budget was allocated to its schools, but lack of funding was often cited as reasons to not fund various initiatives by educational leaders and board of education members. Black and Latinx (Caribbean) students and their communities in the region were overwhelmingly framed negatively, deficitized, and depicted as problems in the various media outlets as well as in the archived documents analyzed in this study. For example, The Connecticut Law Tribune, an influential legal publication framed Urbanville Elementary School, led by Marcus King the only Blackamerican principal in the district, as in a 'rough part' of Urbanville filled with 'blighted homes' impoverished families and struggling English Learners needing special education (Spicer 2016, para., 1).

In 2011, the Urbanville elementary school had implemented a federally funded school takeover policy known as Turnaround, following the 2010 reauthorization of ESEA 1965 and Title I funding. The policy provided significant monetary incentives for eligible schools which scored in the lowest five percent state-wide on standardized English and math tests. Policy enactment led to drastic leadership changes 
and upheaval throughout the district. For example, principal Marcus King was demoted and removed from Urbanville elementary school to much resistance from various Black and Brown community members and parents of Urbanville elementary school who were concerned with the trajectory of the school district. In 2013 King filed a high-profile racial discrimination suit against the Urbanville Board of Education and its superintendent, and by late 2017, an undisclosed financial settlement was reached (Gagne 2017).

\section{Methods}

We used discursive policy analysis focusing on undemocratic discourses and practices around the enactment of a mayor-led turnaround policy in the Urbanville district. We sought to examine undemocratic practices and policy discourses that framed minoritized students and communities; and the ways in which the community, parents, and students, responded. Discursive policy analysis was appropriate for this study because it provided the analytic framework which allowed for more broadened angles of inquiry and critical analysis of the underlying narrative policy elements, symbols, and language that define the policy process from legislation to local enactment.

\section{Data sources and participants}

Data sources include interviews and critical analysis of archived documents. The first author of this study conducted seven semi-structured interviews with educational leaders and administrators, community leaders, and a local retired state legislator over a period of two years (2015-2017) with follow-ups and clarification up until 2019. We also collected board of education meeting minutes, state and local reports on policy (budgetary decisions; teacher surveys), and media content published between 2013 and 2019 for our document analysis. We purposively selected the seven interview participants for this study. Six participants identified as Black; five identified as Blackamerican, one identified as Afro-Caribbean, and one identified as white. Table 1 provides detailed participant profile. 
Table 1. Participants of The Study.

\begin{tabular}{|c|c|}
\hline Name* & Biographical Information \\
\hline Dr. William Richardson III & $\begin{array}{l}\text { The first African American principal in the city of Urbanville and the } \\
\text { first African American principal at Urbanville elementary (1973-1986). }\end{array}$ \\
\hline Mr. Devin Croft & $\begin{array}{l}\text { A former biology researcher at Yale University. Mr. Croft left Yale to } \\
\text { teach high school biology in one of the state's largest urban school } \\
\text { districts in the mid-196os. Former high school principal of large } \\
\text { urban high school in Urbanville area in the } 1980 \text {. The State central } \\
\text { office administrator with the department of education in the } 1990 \text { s. } \\
\text { Temporary replacement for Principal King at Urbanville elementary } \\
\text { school in 2013. }\end{array}$ \\
\hline Althea Windsor & $\begin{array}{l}\text { A lifelong member of the Urbanville's communities, a member of } \\
\text { the local NAACP, community organizer, activist and president of the } \\
\text { School Governance Council (SGC) at Urbanville elementary school } \\
\text { during principal King's tenure. She was charged with being a liaison } \\
\text { for Urbanville parents. The school governance council was a part of } \\
\text { the state education reform law passed by the State to aid the lowest } \\
\text { performing schools in the state (Public Act 10-111). }\end{array}$ \\
\hline Harold Major Sr. & $\begin{array}{l}\text { A retired former local Urbanville elected official: State Legislator for } \\
20 \text { years. Mr. Major is a community activist and organizer, founder of a } \\
\text { non-profit organization in Urbanville designed to help inner-city youth } \\
\text { and young males with career goals and job training. Major is also a } \\
\text { political science professor at a local community college. }\end{array}$ \\
\hline Kelly Moran & $\begin{array}{l}\text { A White female and former district employee who worked at Urbanville } \\
\text { elementary school prior to principal King's tenure. }\end{array}$ \\
\hline $\begin{array}{l}\text { Marilyn Wilson \& } \\
\text { Karol Hartsfield }\end{array}$ & $\begin{array}{l}\text { Urbanville Board of Education members. They were both able to } \\
\text { expound on public records and questions regarding our document } \\
\text { analysis of school Board of Education meetings. As Urbanville Board of } \\
\text { Education members they provided insight into local policies and policy } \\
\text { debates. }\end{array}$ \\
\hline
\end{tabular}

* Pseudonyms

\section{Data analysis}

We conducted two cycles of analysis to identify patterns and themes (Saldaña 2015). We first individually and collectively read transcripts and documents by highlighting language and excerpts related to 1) undemocratic and deficit framing of minoritized communities and responses, and 2) community engagement/disengagement leadership practices. Analytic memos were used to record our thoughts and to theorize. Further collaborative analysis led to six sub themes: punitive discipline policy, structural inequity and racism, patronizing 
leadership, and cultural insensitivity for the first category and resistance to the policy and mechanisms in leading community disengagement for the second category. This process involved revisiting our original data and analyzing analytic memos.

\section{Author positionality and limitations}

We use the term 'minoritized' instead of minority to describe students and communities to highlight an identity imposed upon them which does not reflect school data or the opinions and perspectives of the broader Black and Brown communities in Urbanville. The first author was raised in Urbanville; he is familiar with the communities, their cultures/epistemologies, and the history and politics in the research site. Although the first author has not lived in Urbanville for many years, he has access to educators, elected officials, community activists, parents, and students throughout the school district. Furthermore, having an outsider, the second author of the study, helped strengthen our analysis by considering multiple possible points of view.

We note that knowledge creation and diffusion are not objective, neutral, nor apolitical (Foucault 1980), therefore our analysis should be understood within the context of the data we collected, and the framework we employed in this study (Holloway and Brass 2018). Thus, our findings need to be interpreted and limited by the documents collected, the participants chosen, the timeframe, and the socio-political contexts of that particular timeframe.

\section{Culture of education policy: enacting deficit policy discourses}

Deficit assumptions and narratives informing policy were discernible in our findings. Local Black and Latinx community activists, which included parents, as well as educators, and administrators in the district experienced policy enactment as patronizing and imposing, as well as inequitable and undemocratic. For example, an anonymous teacher in the district identified three primary challenges facing the district: 'the deeply rooted politics in the district, which transcends individual schools and administrative and teacher placement decisions, the 
low expectation of teachers regarding our student population, and .... teacher bullying that frequently occurs' (Urbanville Minority Teachers 2015, p. 6).

Board of Education Member Karol Hartsfield attributed much of the high expulsion and suspension rate of Black and Latinx students to low expectations of teachers regarding Urbanville students and also to the lack of Black and Latinx representation and role models in the district. She argued, 'people say "oh its poverty” I don't buy that .... we need to infuse into schools representation that is similar to what they [Black and Latinx students] see out here in the world.' These examples of deficit narratives translated into harsh discipline, contemptuous human resource practices, and cultural incompetence impacting the district.

\section{Minor offenses and drastic measures: punitive approaches to discipline}

We first found that deficit assumptions were dominantly reflected in heavy-handed approaches to rule enforcement and school discipline practices. Our interview data especially from parents, community leaders, and school board members pointed out the 'harsh discipline' of minoritized students exacerbated distrust and tensions between the school and community members. Marilyn Wilson, Board of Education member (Board Member), noted: 'We noticed a lot of minorities and children of color are being arrested far more than their counterparts ... Our [Blackamerican students] suspension rate is one of the highest .... our kids get suspended for the dress code violations far more than anyone else.'

Our document analysis supported her claim. According to a state report, in the so called 'poorest urban areas' of which Urbanville was identified; students 'were arrested 23 times more often, expelled more than 17 times more often, suspended out of school 24 times more often and suspended in school nearly 10 times more often than those in wealthy white suburban areas' (Iverson, Joseph and Oppenheimer 2015 , p. 2). One of the most egregious acts of school discipline occurred in one of Urbanville's majority Black and Latinx high schools, Garvey High School. ${ }^{2}$ At Garvey $84 \%$ of its students are Latinx and Black while $83 \%$ of staff are white. In May of 2017 , in an effort to 
'crack down' on dress code violations, Garvey High School made national news for suspending 150 students in one day. The newspaper cited that a Garvey High School 16-year-old Black female honor student was 'caught up in the sweep' and when she offered to remove her sweatshirt, stating, 'I'd rather be cold than suspended,' school officials told her 'It's only one day. You'll get over it' (Schladebeck 2017, para., 1-2).

Such punitive language and action utilized in school discipline seemed to draw a line between parents and school officials in the school district. School officials said that the Garvey High dress code was put in place to help foster a focused learning environment and to reduce the cost of clothing worn to school (Schladebeck 2017). However, Althea Windsor, who worked as a liaison between the school officials and parents in the district, refuted the statement by school officials; stating that 'no parents were invited to these meetings with the school board.'

Board Member Karol Hartsfield indicated discrepancies between political interests from state government and local government (Urbanville Mayor) and the school board in representing minoritized groups. Hartsfield stated very explicitly that the mayor enacts school policy based on political motives and 'not what the parents want. And that's very evident .... I'm very involved in the community' describing herself as accessible in comparison to her colleagues stating that they 'can care less.' These discourses and punitive practices are reflective of an established patriarchal ideology operating in the district.

\section{Ideology and structures of inequity and racism: human resource decisions}

Reflecting on the role of Mayoral involvement in educational matters with regard to who the district hired, retained and or terminated, Board Member Marilyn Wilson expressed, 'I think that some things are already known and done before they hit us.' Supporting Wilson's comment, our analysis revealed rampant deficit assumptions of minoritized communities which were supported by governmental systems and bureaucracies, which failed to support the district's recruitment and retention of Black and Latinx teachers. For instance, 76 percent of the Black and Latinx teachers considered employment elsewhere 
due to a lack of administrative support, the lack of mobility, feeling isolated, ignored and not valued by their peers and administrators. Additional reasons included 'nepotism,' and 'inconsistent discipline' practices; district climate was identified as a 'good ole boy network' (Urbanville Minority Teachers 2015, pp. 5-6).

The district not only failed to recruit new educators from minoritized communities, but also lost many of the exceptional ones who represented minoritized perspectives. In her interview, Board Member Marilyn Wilson recalled, 'We just lost one of our highest-ranking African Americans [school administrators to another district within the state] she was in charge of hiring and recruitment and everyone is pissed off because we lost her.'

Patronizing educational leadership: nepotism and milking the system

Educational leadership should be reformed to reflect inclinations to be responsive and respectful towards the communities and cultures that students bring into their schools (Khalifa 2018a, 2018b). Instead, what we found were longstanding and problematic practices posing as reform. For example, the district announced the hiring of a turnaround supervisor, a high-ranking position that the mayor voiced excitement about during the board of education meeting. At that same board of education meeting, Gerald Johnston, a former NAACP president and community activist dating back to the 196os, stated that the Urbanville school system for years has made very little progress with hiring Blackamerican and Latinx teachers, and administrators (Urbanville Board of Education 2013). In regards the turnaround supervisor position, Johnston accused school leadership of political cronyism and nepotism, stating,

It's time to stop and pay attention to the children in our system. This is not about a bunch of families, who milks the trough and goes and lives in [high SES Urbanville suburbs] .... none of our teachers, and administrators live in [Urbanville] .... And then you're insensitive to our children. This [has] got to stop (Urbanville Board of Education 2013, p. 17).

Such examples illustrate a district that is unresponsive and patronizing toward community leaders and parents. Furthermore, examples 
of insensitivities toward minoritized students in the district, their communities, and culture were pervasive with explicit examples found throughout our data.

\section{Cultural (in)competence and fundamental contrasts}

Parents in general expressed feeling unsupported and unwelcomed in Urbanville schools. For example, Board Member Marilyn Wilson stated that: 'I think [there is a] disconnect between the school and parents; parents don't feel they are welcomed. . . . a lot of times they feel they are being belittled and they are not getting that respect.' She added 'we have gotten a lot of complaints [of parents feeling unwelcomed] ... I think that they [school officials] should be able to take the advice that the parents [are] giving them about their child, because who knows your child better than you?'

In contrast, we also found explicit descriptions and examples of the culturally competent leadership of Mr. King as a salient response to the various explicit mentions of insensitive practices pervading the district. For example, Althea Windsor ${ }^{3}$ who worked closely with Mr. King described him as a 'culturally competent' urban educator capable of developing teachers who 'fall short' in areas. She further explained that King earned the respect of parents due to his 'love' of his students.

These contrasts are rooted in leadership which is insensitive to its students, communities, and their culture. This resonates with Board Member Karol Hartsfield's comment that 'our curriculum needs to reflect and be sensitive to the culture of the kids and their experiences. And we need the central office to reflect the cultural aspects of these kids' world and be more sensitive to that.' In these leadership practices, racialization played a significant role in the contrasting discourses shaping how schools and the minoritized students and communities were framed.

\section{Democratic struggles and minoritized community engagement in education}

The ways in which parents and community activists came together, in response to deficit-oriented discourses and the enactment of policy, was one of the most intriguing findings in this study. The 
interconnection between parents in the district and their ability to connect to a broad community of empathetic stakeholders set in motion a formidable level of activism and resistance that the district leadership had not anticipated. This section highlights community resistance as a form of democratic participation. We found that Mr. Croft and Dr. William Richardson III, two Blackamerican educators each with nearly 40 years of experience in urban schools in the state, both valued parental involvement and community engagement and deemed them as two sides of the same coin. Mr. Croft describes himself as a 'huge advocate of parental involvement' who scoffs at rhetoric that 'parents don't care' and believes that 'more money [should be] geared toward working with parents and their communities.'

\section{Resistance to deficit based and undemocratic policy enactment and mobilization}

"They never want to anger a sleeping giant."

This statement by Dr. William Richardson III, was made in reference to his experiences as the first Blackamerican principal in Urbanville and his success during his tenure in which he attributed to 'cultivating' and 'maintaining strong community and parent relationships.' Dr. Richardson referenced the community and parents in Urbanville as 'sleeping giants.'

The punitive approaches to discipline, unequal human resource decisions, lack of cultural responsiveness, and the various racialized elements adversely affecting policy enactment targeting minoritized populations found in this paper represent fundamental encroachments of democratic principles. Resistance ensued in Urbanville through a loosely connected coalition of parents, community activists, school administrators, educators, and politicians from across Black and Latinx communities; along with some key white allies connected to the city and the district.

A board of education meeting held on 31 July 2013 encapsulated this coalition as parents and community activists descended upon the meeting and expressed their frustration with policy enactment and the direction of the school under the leadership of the mayor. Althea Windsor addressed the board of education on behalf of 60 Urbanville 
Elementary School parents whom she described as 'irate', upon learning that their principal, Marcus King, was removed after the enactment of the Turnaround policy. In reviewing the minutes taken from that meeting, Windsor stated that the role taken by the district leadership had 'destroyed the morale of that community' stating 'I have 60 signature complaints for a petition that says we want our principal (Marcus King) back' (Urbanville Board of Education 2013, p. 4).

There has been a significant amount of resistance to what we identified as deficit based and undemocratic policy enactment in the district. The mobilization of parents and community members brought noteworthy attention to the district and fostered important dialogues which have resonated throughout the state and across various political arenas. For example, on 20 August 2015 powerful state and local interests gathered to discuss a wide range of issues found in the district, including the role of parents in schools, and the racially disproportionate number of school suspensions and arrests. The National Association for the Advancement of Colored People (NAACP) and many of the city's civic, education and political leaders including 'four city alderman, four Board of Education members and several of the schools' top officials' along with parents and community activists gathered to discuss the deficit based and undemocratic policy enactments plaguing many of the district's schools (Puffer 2015, para. 2).

\section{Mechanisms in leading community (dis)engagement from mi- noritized communities}

Our analysis shows that disengagement from the minoritized communities can be explained by two mechanisms: redistributing justice and racial economic segregation. Thus, disengagement in this context of undemocratic, unjust praxis can be understood as resistance to these mechanisms, which can also mean the active participation in democracy, which we found in the minoritized communities in Urbanville.

\section{Redistributing justice}

The ways that school leadership prevented and/or rejected engagement from minoritized communities appeared to be mostly ideological related to white supremacy, social economic status (SES), or English 
language (EL) status. Gerald Johnston, long-time community activist, characterized the discipline of Marcus King by the district's leadership as 'literally a public lynching ... between the school board and the newspaper' (Urbanville Board of Education 2013, p. 17).

The many glowing depictions of Mr. King by a wide range of minoritized community members and parents as a loving and competent educator contrasted with the ways that the white local school leaders and media framed Mr. King. For example, the mayor of Urbanville, an ex officio board of education member, and former City of Urbanville police chief, and former board of education member stated at the 31 July 2013 Board of Education meeting that Mr. King was too inexperienced and unqualified to be a head principal (Urbanville Board of Education 2013). The mayor claimed that; 'sincerely, for years, parents, teachers, students have expressed to me in my role as Police Chief, School Commissioner, and most recently as Mayor, how disappointed they were with (Urbanville Elementary) School' under the leadership of Marcus King (Urbanville Board of Education 2013, p. 30). The mayor openly supported the superintendent and lauded her for her 'courage' to remove Marcus King.

\section{Racial-economic segregation}

Harold Major Sr. ${ }^{4}$ helps to connect the undemocratic assumptions and deeper meanings of stated educational policy goals (e.g., equity, closing gaps, segregation, etc.) with contrasting overall school-based outcomes. He asserted that discriminatory systems, practices, and deficit perceptions are exacerbated by inequitable educational funding processes based upon property taxes, which he called 'the engine for public education.' Major Sr. argues that fundamental to these discriminatory practices and deficit-laden assumptions are discourses based 'on the premise that if you have money with a reliable tax base you can spend more money and the education is supposed to be better.' For example, enactment of Turnaround would guarantee several million dollars based upon federal guidelines for low standardized test scores. Some schools in Urbanville met the low-performance criteria. However, a closer look at the Urbanville school districts' budget reveals more questions than answers. For example, Urbanville spends about 18, ooo USD per student, and the student to teacher ratio is 
notably better than the state and national averages (Department of Education 2018).

A Democratic State Senator highlighted 'unconscionable levels of racial and economic segregation' in the state (Rabe Thomas 2016, para., 1). In his talk with minoritized student leaders in Connecticut High Schools, he concluded that 'they know that they were being robbed from an experience that other students in Connecticut benefitted from,' and added that '[students] felt that it was totally intentional, and there is no way to read the increasing isolation of high-poverty students and minority students other than its result of intentional decisions made by policymakers' (Rabe Thomas 2016, para., 15). This perspective reflects patronizing, unresponsive, and imposing educational leadership practices in spite of, as in this case, concerns from local politicians and elected officials.

\section{State and Local Level Deficit Praxis}

We found evidence that racial-economic segregation in Urbanville reflected state level practices regarding budget decisions. For example, in 2017, Connecticut Gov. Dannel P. Malloy crafted a 230 million USD budget proposal to increase state education grants to 52 cities and towns' struggling schools. The governor's proposal allowed for cities and towns to use the money however they saw fit. Patrice McCarthy, the deputy director of the Connecticut Association of Boards of Education critically warned:

That could be a problem. Obviously if a community is not required to spend it on education, then it's not education aid .... [these funds are not] going to go to support student needs in most communities .... It's important that people understand that education grants might not be being spent on education. (Rabe Thomas 2017, para. 2)

Urbanville was included in this aid increase and our interviews with Urbanville community members echoed the sentiment of Patrice McCarthy. Board Member Karol Hartsfield suggested that controlling the budget was a critical tool of school governance and that over sixtypercent of the entire city budget was allocated to education. At the 
Urbanville Board of Education meeting on July, 31, 2013, community activist Leslie Liston indicated that she had met with State Commissioner of Education Stefan Pryor 'many times, face to face' regarding concerns of 'the possible reallocation of monies' (Urbanville Board of Education Meeting Minutes, 2013, p. 3-4). Such problematic practices speak directly to schools disengaging from minoritized communities and resistance from the community to clear undemocratic practices.

\section{Removing a Beacon of Hope}

In 2013, Marcus King, the only Black principal in the district at the time was demoted from head principal and removed from Urbanville elementary. This decision caused significant community uproar and support from minoritized community organizations and parents from across the state. Mr. King filed a 1 million USD federal lawsuit against the Urbanville Board of Education and its superintendent. The suit claimed that 'white principals weren't punished in the same manner for similar conduct' (Spicer 2016, para., 2). In March of 2016, U.S. District Court Judge declared that 'there is enough evidence of possible racial discrimination to allow the suit to continue' (Spicer 2016, para., 11). In August of 2017, attorneys for both sides confirmed that a settlement had been reached in Mr. King's racial discrimination/civil complaint against the Urbanville Board of education and its superintendent, the details of which are confidential (Gagne 2017). This case suggested that the prevalent racial discrimination and segregation in the district, combined with the pervasive political and bureaucratic authorities, discouraged healthy engagements between school leadership and the minoritized communities in Urbanville.

\section{Discussion}

Our findings uncover pathological policy discourses, hegemonic assumptions, and deficit frames of minoritized communities embedded in policy enactment and carried out by disengaged leadership practices, which led to resistance from the minoritized communities. Supported by literature (Anderson 1998; Ishimaru 2014; Ishimaru et al. 2016; Luet, 2017; Stein 2004), we argue that community 
disengagement revealed in the case of Urbanville can be understood as the stance taken by minoritized communities who are compelled to resist undemocratic enactment of education policy and leadership practices. This disengagement we conceptualize as not disengaging from the care and concern for their children but a disengagement from what Stein (2004) calls culture of education policy; exemplified with the mandates of unjust discourses, assumptions, and their restrictive force undergirding educational policy and school systems.

This paper expands research on community engagement leadership by exploring structures and discourses informing policy and practice found to impede individual leaders' initiatives to engage with minoritized communities and students. Analyzing policy as discursive praxis enabled us to examine hidden or otherwise unarticulated mechanisms and processes. For example, our findings revealed deficit-oriented norms and racialized social structures behind punitive discipline approaches and human resource decisions. Under the lawenforced and politically driven administrative approaches, combined with policy discourses deficitizing and isolating the urban district, we witnessed patronizing educational leadership that consistently missed opportunities to engage the cultural norms and epistemologies found in the Urbanville communities. Thus, disengagement from the minoritized communities should be understood as resistance to unjust, undemocratic ways of thinking, its pathological frameworks and practices, and assaults upon minoritized communities' epistemologies and norms, which has been prevalent in education policy legislation and enactment in American schools (Ishimaru et al. 2016; Stein 2004). In doing so, we link education policy, leadership practices, and norms to cyclical policy and leadership discourses and praxis that fuel disengagement.

In addition, our critical policy analysis showed extant discourses and policy enactment that can be understood as the product of patronization and bias, informed by Eurocentric epistemological norms, practices, and mindsets often found in the historical and political context of US education (Battisete 2013; Mackey 2017; Wright et al., 2018). These patronizing approaches were apparent in spite of a multitude of contrasting perspectives and concerns raised by politicians, administrators, educators, community organizers, parents and students from and within Urbanville's urban communities. The educational policies 
that were enacted under the guise of fixing the problems in these urban communities did not reflect perspectives from the most educated, politically astute educators, administrators, politicians, and community activists advocating on behalf of the majority-minority school district. The analysis of the Urbanville school district supports a global phenomenon of ideology that values white ways of knowing (epistemologies), culture, and perspectives even in instances where little or no gain can be ascertained, such as in instances where very few, if any, white students will be impacted (e.g., Crozier 2014; Gillborn 2005; Mackey 2017; Stein 2004).

Our findings also provide implications for turnaround reforms as a part of consequence- based accountability prevalent in the US and other international contexts (Bowman 2013; Kim, 2020; Meyers and Smylie 2017; Morel, 2018; Wright et al., 2018). While logics behind school turnaround can be seen as a technical remedy to fix low-performing schools (Meyers and Smylie 2017), critical analysis of this study revealed that such punitive, consequential accountability approaches can reify and perpetuate undemocratic and deficit views on racially minoritized communities and students by framing them as 'potentially dangerous and disruptive' (Stein 2004, p. 59). Thus, leadership praxis needs to be expanded to critically read what is behind the text (policies), considering turnaround mechanisms combined with racially unjust rhetoric and structures.

We believe that this study helps open a space to form authentic coalitions and research partnerships with minoritized communities led by community members and driven by community generated problems of practice. Our findings suggest that the knee-jerk educational policy reactions that are reifying and revising deficit-based discourses, narratives, and practices should be abandoned by researchers, leadership preparation programs, and educational leaders. As a result, policymakers must begin to turn their attention towards generating policy solutions from the perspectives of those whom the policy affects as a critical shift in priority; a distinct reversal from continuously attempting to generate policy solutions from the top down. 


\section{Notes}

1. We used a pseudonym for the district in references to protect the district.

2. The first author is a graduate of Garvey High School.

3. Education advocate and community organizer; was the school governance council president in Urbanville Elementary School and charged with being a liaison for Urbanville parents. As a school governance council president, she worked closely with Mr. King.

4. Major Sr. is a retired State Legislator of over 20 years, a community organizer, a local college professor and a highly respected member of the Blackamerican community in Urbanville. As a lifelong government official and city and state politician; his perspective on local school policy was significant.

Disclosure No potential conflict of interest was reported by the authors.

\section{The Authors}

James S. Wright (PhD) is an Assistant Professor of Educational Leadership at San Diego State University. His research agenda is highlighted by the ways in which culture affects educational policy and leadership. Specifically, he looks at how culture and discourses of culture shape educational policy and their implications for culturally responsive leadership practices in education.

Taeyeon Kim is an assistant professor in the Department of Educational Administration at the University of Nebraska-Lincoln

\section{References}

Abraham, S., B. A. Wassell, K. M. Luet, and N. Vitalone-Racarro. 2019. "Counter Engagement: Parents Refusing High Stakes Testing and Questioning Policy in the Era of the Common Core." Journal of Education Policy 34 (4): 523-546.

Anderson, C. 2016. White Rage: The Unspoken Truth of Our Racial Divide. New York: Bloomsbury USA.

Anderson, G. L. 1998. "Toward Authentic Participation: Deconstructing the Discourses of Participatory Reforms in Education." American Educational Research Journal 35 (4): 571-603. Anderson, J. 1988. The Education of Blacks in the South, 1860-1935. Chapel Hill: University of North Carolina Press.

Arsen, D., T. Deluca, Y. Ni, and M. Bates. 2016. "Which Districts Get into Financial Trouble and Why: Michigan's Story.” Journal of Education Finance 42 (2): $100-126$. 
Auerbach, S. 2010. "Beyond Coffee with the Principal: Toward Leadership for Authentic School-family Partnerships.” Journal of School Leadership 20 (6): 728-757.

Bacchi, C. 2000. "Policy as Discourse: What Does It Mean? Where Does It Get Us?" Discourse: Studies in the Cultural Politics of Education 21 (1): 45-57.

Ball, S. J. 1993. "What Is Policy? Texts, Trajectories and Toolboxes." The Australian Journal of Education Studies 13 (2): 10-17.

Battiste, M. 2013. Decolonizing Education: Nourishing the Learning Spirit. Saskatoon, Canada: Purich Publishing.

Bowman, K. L. 2013. "State Takeovers of School Districts and Related Litigation: Michigan as a Case Study." The Urban Lawyer 45 (1): 1-19.

Crouch, C. 2016. “The March Towards Post-democracy, Ten Years On.” Political Quarterly 87 (1): 71-75.

Crowson, R. L., and W. L. Boyd. 2001. "The New Role of Community Development in Educational Reform." Peabody Journal of Education 76 (2): 9-29.

Crozier, G. 2014. "International Perspectives on Contexts, Communities and Evaluated Practices. Family-school-community Partnerships.” Journal of Education Policy 29 (2): 280-282. Della Porta, D. 2015. Social Movements in Times of Austerity: Bringing Capitalism Back into Protest Analysis. 1 ed. Cambridge, UK; Malden, MA: Polity.

Department of Education 2018. Search for Public School Districts - Retrieved April 21, 2019, from National Center for Educational Statistics. https://nces.ed.gov/ ccd/districtsearch/district detail.asp?ID2 $=0904830$

Diem, S., M. D. Young, A. D. Welton, K. C. Mansfield, and P.-L. Lee. 2014. "The Intellectual Landscape of Critical Policy Analysis." International Journal of Qualitative Studies in Education 27 (9): 1068-1090.

Duncan, A. 2014 July. "Statement by U.S. Secretary of Education Arne Duncan on the 5oth Anniversary of the Civil Rights Act of 1964. U.S. Department of Education." Speech presented at the 5oth Anniversary of Civil Rights Act of 1964, Washington, D.C. https://www.ed.gov/news/press-releases/statementus-secretary-education-arne-duncan-50th-anniversary-civil-rights-act-1964

Foucault, M. 1980. Power/Knowledge: Selected Interviews and Other Writings 1972-1977. New York: Pantheon.

Fuentes, E. H. 2012. "On the Rebound: Critical Race Praxis and Grassroots Community Organizing for School Change." The Urban Review 44 (5): 628-648.

Gagne, M. 2017, August 16. Urbanville Principal King, City Reach a Settlement. Accessed 8 April 2018. Republican-American website

Gates, S. M., M. D. Baird, B. K. Master, and E. Chavez-Herrerias. 2019. Principal Pipelines: A Feasible, Affordable, and Effective Way for Districts to Improve Schools. Santa Monica, CA: RAND.

Gillborn, D. 2005. "Education Policy as an Act of White Supremacy: Whiteness, Critical Race Theory and Education Reform." Journal of Education Policy 20 (4): 485-505. 
Gillborn, D. 2010. “The Colour of Numbers: Surveys, Statistics and Deficitthinking about Race and Class.” Journal of Education Policy 25 (2): 253-276.

Greenstone, D., \& Peterson, P. E. (1976). Race and Authority in Urban Politics: Community Relations and the War on Poverty. University of Chicago Press.

Henderson, A. T., and K. L. Mapp 2002. A New Wave of Evidence: The Impact of School, Family, and Community Connections on Student Achievement. Annual Synthesis, 2002. https://eric.ed.gov/?id=ED474521

Holloway, J., and J. Brass. 2018. "Making Accountable Teachers: The Terrors and Pleasures of Performativity.” Journal of Education Policy 33 (3): 361-382.

Ishimaru, A. M. 2014. "Rewriting the Rules of Engagement: Elaborating a Model of District-community Collaboration.” Harvard Educational Review 84 (2): 188-216.

Ishimaru, A. M., K. E. Torres, J. E. Salvador, J. Lott, D. M. C. Williams, and C. Tran. 2016. "Reinforcing Deficit, Journeying toward Equity: Cultural Brokering in Family Engagement Initiatives.” American Educational Research Journal 53 (4): 850-882.

Iverson, S., Joseph, E., \& Oppenheimer, C. (2015). Keeping Kids in Class: School Discipline in Connecticut, 2008-2013 (p. 52). http://www.ctvoices.org/ publications/keeping-kids-class-school-discipline-connecticut-2008-2013

Jasis, P. (2013). Latino Families Challenging Exclusion in a Middle School: A Story from the Trenches. School Community Journal, 23(1), 111-130.

Khalifa, M. 2018a. “Centering Ancestral Knowledges: Leadership in Learning Environments.” The Family Leadership Design Collaborative. https:// familydesigncollab.org

Khalifa, M. 2018b. Culturally Responsive School Leadership. http://hepg.org/ hep-home/books/culturally-responsive-school-leadership

Kim, T. (2020). What is the meaning of educational leadership in a time of policy engineering?. International Journal of Leadership in Education, 1-17. https:// doi.org/10.1080/13603124.2020.1770865

Levinson, B. A., M. Sutton, and T. Winstead. 2009. "Education Policy as a Practice of Power: Theoretical Tools, Ethnographic Methods, Democratic Options.” Educational Policy 23 (6): 767-795.

Lindsey, R. B., L. M. Roberts, and F. L. CampbellJones. 2013. The Culturally Proficient School: An Implementation Guide for School Leaders. Thousand Oaks, CA: Corwin.

Luet, K. M. 2017. "Disengaging Parents in Urban Schooling.” Educational Policy 31 (5): 674-702. 18 J. S. WRIGHT AND T. KIM

Mackey, H. J. 2017. “The ESSA in Indian Country: Problematizing Selfdetermination through the Relationships between Federal, State, and Tribal Governments.” Educational Administration Quarterly 53 (5): 782-808.

Meyers, C. V., and M. A. Smylie. 2017. "Five Myths of School Turnaround Policy and Practice." Leadership and Policy in School 16 (3): 502-523.

Molla, T., and T. Gale. 2018. "Positional Matters: School Leaders Engaging with National Equity Agendas.” Journal of Education Policy 34 (6): 858-876. 
Morel, D. 2018. Takeover: Race, Education, and American Democracy. New York, NY: Oxford University Press.

Puffer, M. 2015, August 21. "School Arrests Debated Education, City Officials at NAACP Forum.” Urbanville Republican-American. http://www.rep-am.com/ articles/2015/08/21/news/local/902655.txt

Rabe Thomas, J. 2016, July 12. Murphy Calls Segregated CT Schools "Unconscionable," Proposes Bill. Accessed 24 September 2018. https://ctmirror.org/2016/07/12/ murphy-calls-segregated-ct-schools-unconscionable-proposes-bill

Rabe Thomas, J. (2017, February 8). Some education aid increases might not be spent on schools. The CT Mirror. https://ctmirror.org/2017/02/08/ some-education-aid-may-not-be-spent-on-schools/

Radd, S. I., T. J. Grosland, and A. G. Steepleton. 2019. "Desegregation Policy as Cultural Routine: A Critical Examination of the Minnesota Desegregation Rule." Journal of Education Policy. doi:10.1080/02680939.2019.1609092.

Saldaña, J. 2015. The Coding Manual for Qualitative Researchers. Thousand Oaks, CA: Sage.

Schladebeck, J. 2017, May 6. High School Suspends 150 Students for Dress Code violations-NY Daily News [Online Newspaper]. Accessed 9 July 2017. http://www.nydailynews.com/news/national/ high-school-suspends-150-students-dress-code-violations-article-1.3141969

Schutz, A. 2006. "Home Is a Prison in the Global City: The Tragic Failure of School-based Community Engagement Strategies." Review of Educational Research 76 (4): 691-743. https:// doi.org/10.3102/o0346543076004691

Singh, N. P. 2018, September. "From Nation State to Empire State." Speech presented at the Lannan Foundation, Santa Fe, New Mexico. Retrieved from https://itunes.apple.com/us/podcast/intercepted-with-jeremy-scahill/id119520 $\underline{6601}$ ? $\mathrm{mt}=2 \& \mathrm{i}=1000421146260$

Smyth, J. 2006. "Educational Leadership that Fosters 'Student Voice'." International Journal of Leadership in Education 9 (4): 279-284.

Smyth, J., and J. Robinson. 2015. “'Give Me Air Not Shelter': Critical Tales of a Policy Case of Student Re-engagement from beyond School.” Journal of Education Policy 30 (2): 220-236.

Spicer, M. 2016. “Judge Allows Black School Principal's Discrimination Lawsuit to Move Forward.” Connecticut Law Tribune, March 15.

Stein, S. J. 2004. The Culture of Education Policy. New York: Teachers College Press.

Trujillo, T. M., Hernández, L. E., Jarrell, T., \& Kissell, R. (2014). Community Schools as Urban District Reform: Analyzing Oakland's Policy Landscape Through Oral Histories. Urban Education, 49 (8), 895-929. https://doi. org/10.1177/0042085914557644

Urbanville Board of Education Meeting Minutes. 2013. Urbanville Board of Education [Urbanville Board of Education Minutes Rescheduled Meeting]. 
Urbanville Minority Teachers. 2015. Urbanville Public School District Action Plan to Increase Representation of Black and Latino Educators [Plan of Action]. Urbanville, Connecticut: State of Connecticut Department of Education.

Warren, M. 2014. "Transforming Public Education: The Need for an Educational Justice Movement." New England Journal of Public Policy 26: 1. https:// scholarworks.umb.edu/nejpp/vol26/iss1/11

Warren, M. R. 2005. "Communities and Schools: A New View of Urban Education Reform.” Harvard Educational Review 75 (2): 133-173.

Warren, M. R. 2011. "Building a Political Constituency for Urban School Reform." Urban Education 46 (3): 484-512.

Wright, J. S., \& Tabrizi, R. (2020). Between a Rock and a Hard Place: Minoritized Communities, Urban School Reform, School Policies, and Mayoral Control. Journal for Leadership, Equity, and Research, 6 (1), Article 1. https://journals. sfu.ca/cvj/index.php/cvj/article/view/75 